\section{Seizures after antiemetic treatment with high dose domperidone: report of four cases}

The judicious use of antiemetic treatment has made chemotherapy tolerable for a considerable number of patients. ${ }^{1}$ As the dosage of antiemetic drugs is increased, however, so side effects-particularly in the central nervous system-are bound to increase in incidence and severity. We report the occurrence of seizures in four patients treated with high dose intravenous domperidone as prophylaxis against chemotherapy induced emesis. to cause seizures. Epileptic seizures have been described in patients treated with cisplatin ${ }^{5}$ but in our case 3 the patient developed seizures while receiving only intravenous fluids and antiemetic treatment and before receiving any chemotherapy whatsoever. That cardiac arrythmias may have been primarily responsible for the seizures was suggested by the occurrence of ventricular tachycardia-fibrillation in case 3 , which might have been related to the effects of the drug on the vagus nerve.

We conclude that caution should be exercised with the intravenous administration of high dose domperidone, particularly in patients receiving cisplatin. Both the manufacturers of domperidone and the Medicines Control Council of South Africa have been informed of our findings.

Clinical and biochemical data of patients who developed seizures while receiving high dose domperidone

\begin{tabular}{|c|c|c|c|c|c|c|c|}
\hline \multirow{2}{*}{$\begin{array}{l}\text { Case } \\
\text { No }\end{array}$} & \multirow{2}{*}{ Chemotherapy regimen } & \multicolumn{3}{|c|}{ Serum electrolytes $(\mathrm{mmol} / \mathrm{l})$} & \multirow{2}{*}{$\begin{array}{c}\text { Blood } \\
\text { sugar } \\
(\mathrm{mmol} / 1)\end{array}$} & \multirow{2}{*}{$\begin{array}{c}\text { Blood } \\
\text { urea } \\
(\mathrm{mmol} / \mathrm{l})\end{array}$} & \multirow{2}{*}{$\begin{array}{l}\text { Amount of domperidone } \\
\text { administered before } \\
\text { occurrence of seizures } \\
\text { (mg) }\end{array}$} \\
\hline & & $\mathbf{K}^{+}$ & $\mathbf{M g}^{++}$ & $\mathrm{Ca}^{++}$ & & & \\
\hline \multirow{3}{*}{$\begin{array}{l}1 \\
2 \\
3 \\
4\end{array}$} & $\begin{array}{l}\text { Cisplatin } 30 \mathrm{mg} / \mathrm{m}^{2} \text { for three days, doxorubicin } * 60 \mathrm{mg} / \mathrm{m}^{2} \text { for one day, } \\
\text { cyclophosphamide } 600 \mathrm{mg} / \mathrm{m}^{2} \text { for one day } \\
\text { Cisplatin } 20 \mathrm{mg} / \mathrm{m}^{2} \text { for three days, methotrexate } 200 \mathrm{mg} / \mathrm{m}^{2} \text { for one day, }\end{array}$ & $4 \cdot 3$ & 0.76 & $2 \cdot 07$ & $4 \cdot 3$ & $2 \cdot 8$ & 50 \\
\hline & folinic acid rescue & $\begin{array}{l}4 \cdot 2 \\
4 \cdot 2\end{array}$ & $\begin{array}{l}0.77 \\
0.66\end{array}$ & $\begin{array}{l}2 \cdot 32 \\
2 \cdot 12\end{array}$ & $\begin{array}{l}4 \cdot 2 \\
4 \cdot 5\end{array}$ & $\begin{array}{l}6 \cdot 1 \\
2 \cdot 8\end{array}$ & $\begin{array}{r}100 \\
30\end{array}$ \\
\hline & $\begin{array}{l}\text { Cisplatin } 20 \mathrm{mg} / \mathrm{m}^{2} \text { for three days, methotrexate } 200 \mathrm{mg} / \mathrm{m}^{2} \text { for one day, } \\
\text { folinic acid rescue }\end{array}$ & 3.5 & 0.85 & $2 \cdot 30$ & - & $2 \cdot 5$ & 100 \\
\hline
\end{tabular}

*Adriamycin.

Conversion: SI to traditional units-K+ $: 1 \mathrm{mmol} / 1=1 \mathrm{mEq} / 1 . \mathrm{Mg}^{++}: 1 \mathrm{mmol} / 1=2 \mathrm{mEq} / 1 . \mathrm{Ca}^{++}: 1 \mathrm{mmol} / 1=2 \mathrm{mEq} / 1 . \mathrm{Sugar}: 1 \mathrm{mmol} / 1 \approx 18 \mathrm{mg} / 100 \mathrm{ml}$. Urea: $1 \mathrm{mmol} / \approx$ $6 \mathrm{mg} / 100 \mathrm{ml}$.

\section{Clinical series}

Grand mal seizures occurred in four patients being prepared for chemotherapy (table). All were adults with disseminated malignancy being treated with regimens containing cisplatin. The preparation schedule included saline and frusemide diuresis (2 l physiological saline, $20 \mathrm{mmol}(\mathrm{mEq})$ potassium, and $20 \mathrm{mg}$ frusemide given over two to three hours before infusion of chemotherapeutic agents) and prophylactic antiemetic treatment with high dose domperidone. Domperidone was given in a dose of $0.6-$ $1.8 \mathrm{mg} / \mathrm{kg}$ and administered as a slow intravenous infusion of $0.8-2.0 \mathrm{mg} /$ min. Serum electrolyte, blood sugar, calcium, and magnesium concentrations were monitored before chemotherapy and daily while receiving treatment.

Three patients (cases 1,2, and 4) had previously received one to three courses of chemotherapy together with lower doses $(0.4-1.0 \mathrm{mg} / \mathrm{kg})$ of domperidone without having suffered seizures. These three patients had seizures on the second day of treatment cycles 2,3 , and 4 respectively. In all three instances the seizures occurred while domperidone was being infused and before administration of chemotherapy. All three patients continued to receive cisplatin based chemotherapy, but without pretreatment with domperidone and without recurrence of seizures. Investigations including computed tomography and electrolyte and blood sugar estimations (table) failed to show an alternative cause for the seizures. The remaining patient (case 3 ) was due to receive the cisplatin and methotrexate regimen but had a seizure while domperidone was being administered. The seizure was followed by cardiac and respiratory arrest. During attempted resuscitation ventricular tachycardia and fibrillation with large amplitude waves were observed in the electrocardiogram. Despite a 300 joule transthoracic shock irreversible asystole occurred.

\section{Comment}

The control of nausea and vomiting is an important component of chemotherapeutic practice, particularly with the rapidly expanding use of effective but intensely nauseating chemotherapeutic drugs. ${ }^{1}$ Domperidone, a new benzimidazole derivative, has been reported to be very effective for the control of chemotherapy induced nausea and vomiting. ${ }^{2} 3$ The drug is believed to exert its antiemetic effect peripherally at the level of the dopamine receptors in the chemoreceptor trigger zone, ${ }^{4}$ and side effects in the central nervous system are reportedly rare when doses of $0.5-1.0 \mathrm{mg} / \mathrm{kg}$ are used. ${ }^{2}$ Domperidone also has a direct effect on the gut which may be mediated by inhibition of a specific subset of dopaminergic vagus nerve fibres. ${ }^{4}$

The occurrence of epileptic seizures in patients given domperidone has not previously been reported and several factors which may have been responsible in our patients were considered. When compared with other reports the amounts given did not appear to have been excessive either in total quantity or in rate of administration. Other factors which may have contributed were also examined. Electrolyte changes, particularly hypomagnesaemia and hypocalcaemia, may be induced by cisplatin. Although electrolyte abnormalities were detected in some of our patients, none of the changes appeared severe enough
1 Trounce JR. Antiemetics and cytotoxic drugs. $B r$ Med $\mathcal{F} 1983 ; 286: 237-8$.

2 Swann IL, Thompson EN, Quireshi K. Domperidone or metoclopramide in preventing chemotherapeutically induced nausea and vomiting. $\mathrm{Br}$ Med F 1979;ii:1188.

${ }^{3}$ Niemegeers CJE, Schellekeus KHL, Janssen PAJ. The antiemetic effects of domperidone, a novel potent gastrokinetic. Arch Int Pharmacodyn Ther $1980 ; 244: 130-4$.

4 Reyntjens AJ. The antiemetic action of domperidone-a review. Royal Society of Medicine Symposium and Congress Series 1981 ;36:37-9.

5 Mead GM, Arnold AM, Green JA, Macbeth FR, Williams CJ, Whitehouse JM. Epileptic seizures associated with cisplatin administration. Cancer Treat Rep 1982;66:1719-22.

(Accepted 22 March 1984)

Department of Medicine, Haematology and Oncology, Johannesburg Hospital and University of the Witwatersrand Medical School, South Africa

A WEAVING, $\mathrm{MB}, \mathrm{BCH}$, medical officer

W R BEZWODA, MB, PHD, principal physician

D P DERMAN, FCP $(S A)$, senior physician

Correspondence to: Dr W R Bezwoda, Department of Medicine, University of the Witwatersrand Medical School, Parktown 2193, Johannesburg South Africa.

\section{Correction}

\section{Screening for steatorrhoea with an oxalate loading test}

We regret that several mistakes occurred in this paper by Dr D S Rampton et al (12 May, $\mathrm{p}$ 1419).

In the second paragraph the second sentence should have read: "They were all taking an unrestricted diet and were given $300 \mathrm{mg}$ sodium oxalate twice daily in gelatin capsules dissolved in $200 \mathrm{ml}$ of water with lunch and supper for two days."

In the second paragraph of the Patients, methods, and results the conversions of oxalate concentrations into traditional units were wrong. These sentences should have read: "Of the 25 patients with steatorrhoea (median faecal fat excretion $52 \mathrm{mmol} / 24 \mathrm{~h}(14.8 \mathrm{~g} / 24 \mathrm{~h})$; range $20-276 \mathrm{mmol} / 24 \mathrm{~h}$ $(5 \cdot 7-78 \mathrm{~g} / 24 \mathrm{~h})), 23 \mathrm{had}$ hyperoxaluria (median urinary oxalate excretion $0.73 \mathrm{mmol} / 24 \mathrm{~h}(66 \mathrm{mg} / 24 \mathrm{~h})$; range $0.28-2.35 \mathrm{mmol} / 24 \mathrm{~h}(25-211 \mathrm{mg} / 24 \mathrm{~h})$; normal $<0.44 \mathrm{mmol} / 24 \mathrm{~h}(40 \mathrm{mg} / 24 \mathrm{~h})$ ) and two with pancreatic insufficiency and Crohn's disease gave false negative results. Urinary oxalate excretion was significantly lower in the 25 patients without steatorrhoea (median urinary oxalate excretion $0.31 \mathrm{mmol} / 24 \mathrm{~h}(28 \mathrm{mg} / 24 \mathrm{~h})$; range $0.05-0.95$ $\mathrm{mmol} / 24 \mathrm{~h}(5-85 \mathrm{mg} / 24 \mathrm{~h})$ ) ( $<<0.002$, Wilcoxon's two tailed rank sum test). False positive results (urinary oxalate excretion $>0.44 \mathrm{mmol} / 24 \mathrm{~h}(40 \mathrm{mg} / 24$ h)) occurred in. ..."

The second author was Dr D A McCullough. 